\title{
ARTICLE OPEN \\ Synthesis, characterisation and corrosion behaviour of simulant Chernobyl nuclear meltdown materials
}

\author{
Sean T. Barlow ${ }^{1}$, Daniel J. Bailey ${ }^{1}$, Adam J. Fisher ${ }^{1}$, Martin C. Stennett ${ }^{1}{ }^{1}$, Clémence Gausse ${ }^{1}$, Hao Ding ${ }^{1}$, Viktor A. Krasnov $\mathbb{D}^{2}$, \\ Sergey Yu Sayenko ${ }^{3}$, Neil C. Hyatt ${ }^{1 *}$ and Claire L. Corkhill (iD)
}

Understanding the physical and chemical properties of materials arising from nuclear meltdowns, such as the Chernobyl and Fukushima accidents, is critical to supporting decommissioning operations and reducing the hazard to personnel and the environment surrounding the stricken reactors. Relatively few samples of meltdown materials are available for study, and their analysis is made challenging due to the radiation hazard associated with handling them. In this study, small-scale batches of low radioactivity (i.e., containing depleted uranium only) simulants for Chernobyl lava-like fuel-containing materials (LFCMs) have been prepared, and were found to closely approximate the microstructure and mineralogy of real LFCM. The addition of excess of $\mathrm{ZrO}_{2}$ to the composition resulted in the first successful synthesis of high uranium-zircon (chernobylite) by crystallisation from a glass melt. Use of these simulant materials allowed further analysis of the thermal characteristics of LFCM and the corrosion kinetics, giving results that are in good agreement with the limited available literature on real samples. It should, therefore, be possible to use these new simulant materials to support decommissioning operations of nuclear reactors post-accident.

npj Materials Degradation (2020)4:3; https://doi.org/10.1038/s41529-020-0108-z

\section{INTRODUCTION}

On 26th of April 1986, Reactor 4 of the Chernobyl nuclear power plant underwent a catastrophic failure whilst undergoing an experimental power failure test. The reactor experienced uncontrolled fission and water flashed into steam causing an explosion, which exposed the reactor to the atmosphere and caused ignition of the graphite core. It took several days to eventually quell the fire, in which time, radioactive particles were emitted into the surrounding area and the atmosphere, to be spread across the region (now Ukraine, Belarus and Russia) and parts of Europe. This event, classified as Level 7 on the International Nuclear Event Scale (INES), was arguably the most serious nuclear incident to affect the world to date; it is known to have caused 31 direct deaths and a mass evacuation from a $30-\mathrm{km}$ exclusion zone surrounding the reactor, that remains in place today.

During the meltdown of the reactor core, temperatures reached in excess of $1600^{\circ} \mathrm{C}$, which caused the uranium nuclear fuel to melt with the zirconium cladding. ${ }^{1,2}$ This molten material interacted with structural reactor building materials, including steel, concrete, serpentine and sand, forming 100 tons of a glasslike lava that was transported under its own weight to sub-reactor rooms, solidifying in large masses, such as the widely reported "elephants foot". ${ }^{1,3-5}$ Known as lava-like fuel-containing materials (LFCM), these highly crystalline, radioactive, glass-like slags, were found in two main forms, known as Brown and Black lavas. ${ }^{1}$ Crystalline phases observed in both types of LFCM include nonstoichiometric $\mathrm{UO}_{2}$ and $\mathrm{ZrO}_{2}$ from fuel and cladding materials, a $\mathrm{U}-\mathrm{Zr}-\mathrm{O}$ mixed oxide phase and high uranium-zircon $\left(\mathrm{Zr}_{1-\mathrm{x}} \mathrm{U}_{\mathrm{x}}\right) \mathrm{SiO}_{4}$, referred to as "chernobylite"., ${ }^{1,6-9}$ The glassy material in which these crystalline phases reside is a Mg-bearing (from serpentine minerals used in the reactor construction) Ca-aluminosilicate glass, ${ }^{1,6}$ although the actinide and minor fission product content of the glass is not well known. The main differences between
Brown and Black lavas are the extent of crystallisation (greater in the Brown LFCM), the presence of a significant proportion of Febearing phases (Brown LFCM only) and the uranium content (higher in the Brown LFCM). Owing to the heterogeneous nature of LFCM, bulk analysis has yielded a range of compositions, as shown in Supplementary Table 1.

While analysis of samples taken from Chernobyl LFCM was performed over 20 years ago, ${ }^{1-7,10-16}$ the highly radioactive nature of the materials limited the types of characterisation performed. Samples of the material are limited due to the difficulties and dangers associated with their collection (unstable building, high radiation levels), and only a few specimens of the lava that were sampled from within the reactor building have been studied. Despite recent studies, ${ }^{9,17,18}$ little is known about the condition of Chernobyl LFCM, especially now, 33 years after the accident. To overcome this lack of information, past attempts to simulate lowactivity LFCMs (i.e., containing no fission products, only depleted uranium) have been made to help understand the conditions within the reactor during the accident, however, this work was unable to accurately approximate the microstructure, morphology and mineralogy of LFCM. ${ }^{19-22}$

One important aspect of LFCM behaviour that has not yet been investigated in detail is its corrosion behaviour within the reactor building. It is known that, due to the condensation of water inside the roof of the original Chernobyl sarcophagus (as a result of the temperature differential within and outside the structure), and the presence of holes in the sarcophagus roof, a significant proportion of water has dripped onto the LFCM causing it to corrode. ${ }^{16,23}$ This is apparent from the presence of yellow secondary alteration products formed on the surface of LFCM, known to include paulscherrerite $\left(\mathrm{UO}_{2}(\mathrm{OH})_{2}\right)$; studtite $\left(\mathrm{UO}_{4} \cdot 4 \mathrm{H}_{2} \mathrm{O}\right) ; \mathrm{UO}_{3} \cdot 2 \mathrm{H}_{2} \mathrm{O}$ (epiianthinite); rutherfordine $\left(\mathrm{UO}_{2} \cdot \mathrm{CO}_{3}\right)$; schoepite $\left(\left(\mathrm{UO}_{2}\right)_{8} \mathrm{O}_{2}(\mathrm{OH})_{12} \cdot 12 \mathrm{H}_{2} \mathrm{O}\right), \mathrm{Na}_{4}\left(\mathrm{UO}_{2}\right)\left(\mathrm{CO}_{3}\right)_{3}$ and the

\footnotetext{
${ }^{1}$ NucleUS Immobilisation Science Laboratory, Department of Materials Science and Engineering, The University of Sheffield, Sheffield S1 3JD, UK. ${ }^{2}$ Institute for Safety Problems of Nuclear Power Plants, National Academy of Sciences of Ukraine, Kyiv Oblast, Ukraine. ${ }^{3}$ National Science Center Kharkov Institute of Physics and Technology, Kharkov, Ukraine. *email: n.c.hyatt@sheffield.ac.uk; c.corkhill@sheffield.ac.uk
} 


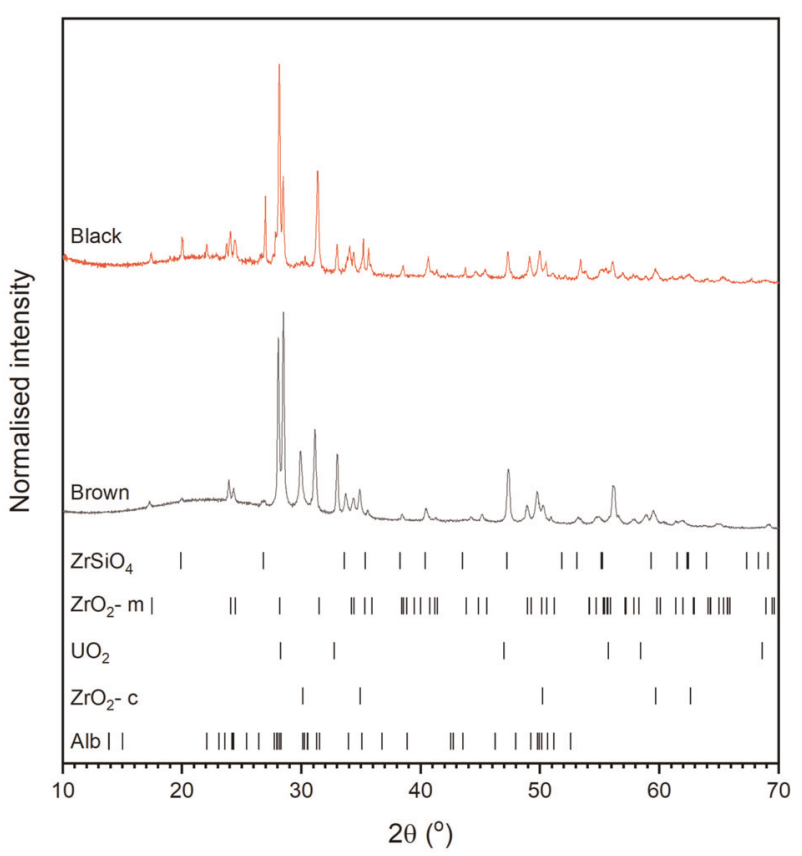

Fig. 1 Powder X-ray diffraction data obtained for simulant Brown and Black LFCM compositions.

sodium carbonate phases $\mathrm{Na}_{3} \mathrm{H}\left(\mathrm{CO}_{3}\right)_{2} \cdot 2 \mathrm{H}_{2} \mathrm{O}$ and $\mathrm{Na}_{2} \mathrm{CO}_{3} \cdot \mathrm{H}_{2} \mathrm{O}$. $1,18,24,25$ These phases have potential to generate significant amounts of radioactive, uranium-bearing dust when the humidity within the sarcophagus falls below $85 \%$. $^{23,26,27}$

Understanding the corrosion behaviour of LFCM, and developing a detailed evaluation of the kinetics and mechanisms of dissolution, are vital to support ongoing decommissioning efforts-both at Chernobyl and also at the Fukushima Daiichi Nuclear Power Plant, where LFCM-type materials are thought to have formed, which largely remain submerged in water used to cool the melted core. As such, in this study, we present the results of an investigation to synthesise low radioactivity, accurate simulant LFCMs and perform a preliminary evaluation of their corrosion behaviour.

\section{RESULTS}

Lava-like fuel-containing material microstructure and phase analysis

Analysis of Brown and Black LFCMs revealed a microstructure and mineralogy consistent with real Chernobyl LFCM materials, e.g., ref. ${ }^{1}$ A glass-like material containing crystallites was confirmed for both materials by XRD (Fig. 1), with a region of diffuse scattering present between $15^{\circ}<2 \theta<35^{\circ}$ and Bragg reflections indexed as: $\mathrm{UO}_{2}$ [PDF 71-0258]; monoclinic $\mathrm{ZrO}_{2}$ [PDF 78-1807]; cubic $\mathrm{ZrO}_{2}$ [PDF 81-1550]; $\mathrm{ZrSiO}_{4}$ [PDF 72-0402] and albite $\left(\mathrm{NaAlSi}_{3} \mathrm{O}_{8}\right.$ ) [PDF 41-1480]. The expanded unit-cell parameter of the cubic $\mathrm{ZrO}_{2}$ phase, $a=5.150$ (4) $\AA$, compared with the reference data, $a=5.135$ (9) $\AA$, is consistent with the formation of cubic $\left(Z_{1-x} U_{x}\right) O_{2}$. The reflections indexed as $\mathrm{ZrSiO}_{4}$ appeared to be more intense in the Black LFCM. The presence of these phases was confirmed by SEM/ EDS analysis of each material, as shown in Fig. 2 and Supplementary Fig. 1. Phases containing $\mathrm{Zr}$ and $\mathrm{U}$ (i.e. $\left(\mathrm{Zr}_{1-\mathrm{x}} \mathrm{U}_{\mathrm{x}}\right)$ $\mathrm{O}_{2}$ ) had a cubo-octahedral, fused, or dendritic morphology, consistent with textures observed in real LFCM. ${ }^{1,11,17}$ Furthermore, spherical inclusions containing $\mathrm{Fe}, \mathrm{Cr}$, Ni and Mo were observed, arising from the addition of stainless steel to the samples prior to thermal treatment (Supplementary Fig. 1). (a)

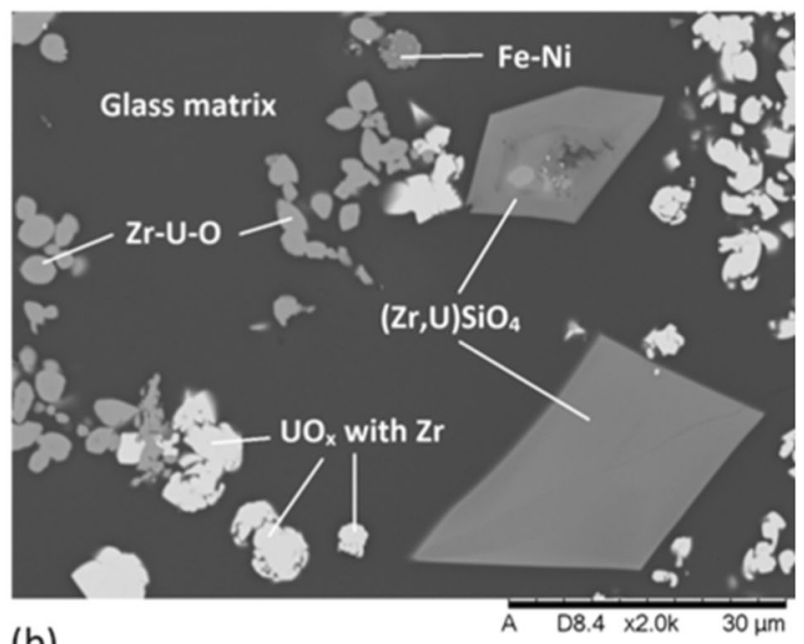

(b)

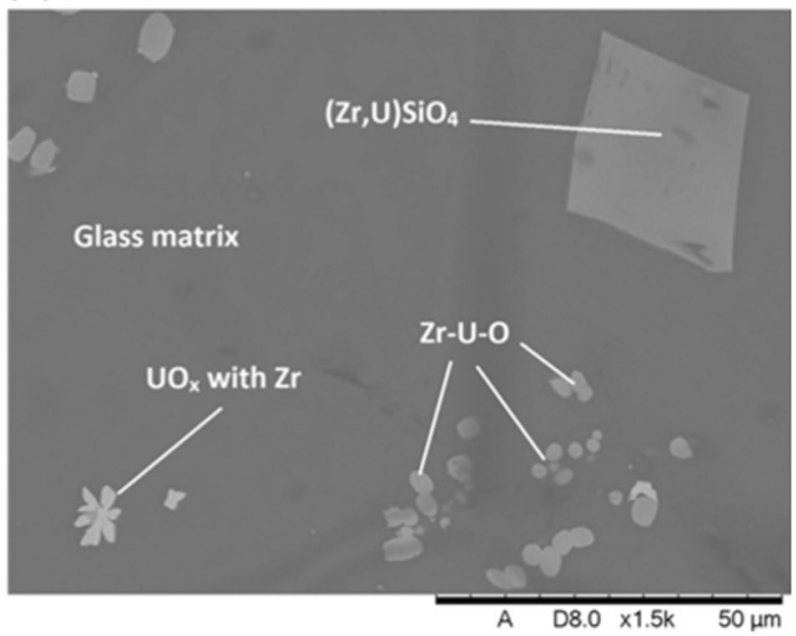

Fig. 2 Back-scattered electron images of simulant LFCM. Highlighting phases identified with the aid of EDX and XRD for (a) Brown and (b) Black LFCM compositions.

Previous studies that aimed to simulate LFCM were unable to promote the formation of U-rich zircon, often referred to as chernobylite $\left[\left(\mathrm{Zr}_{1-x} \mathrm{U}_{\mathrm{x}}\right) \mathrm{SiO}_{4}\right]$, which is present in real LFCM. ${ }^{19-21}$ Since most of the $Z r$ present in the LFCM partitions into crystalline phases, and the reported $\mathrm{Zr}$ concentrations of real LFCM (Supplementary Table 1) are averaged electron probe microanalysis or EDS measurements across the whole sample (including lower $\mathrm{Zr}$-content glass), it is possible that previous attempts to force crystallisation of chernobylite were unsuccessful due to an under-estimation of the $\mathrm{Zr}$ content. In this study, through the addition of excess $\mathrm{ZrO}_{2}$ it was possible to promote crystallisation of high uranium-zircon, as shown in Fig. 3. The U-containing zircon had a characteristic bi-pyramidal shape with distinct growth zonation; EDS data averaged over several U-bearing zircon crystallites gave an approximate composition of $\left(\mathrm{Zr}_{0.95} \mathrm{U}_{0.05}\right) \mathrm{SiO}_{4}$ for the Black LFCM and approximately $\left(\mathrm{Zr}_{0.90} \mathrm{U}_{0.10}\right) \mathrm{SiO}_{4}$ for Brown LFCM. The incorporation of $\sim 5 \mathrm{wt} \%$ and $10 \mathrm{wt} \% \mathrm{U}$ in zircon from simulated Black and Brown lavas is in good agreement with literature values $\left(5.6 \mathrm{wt} \%\right.$ and $11.3 \mathrm{wt} \%$, respectively). ${ }^{17}$ At the centre of several of the zircon crystals, small Zr-bearing inclusions were observed (e.g., Fig. 3c). Such inclusions were observed in real Brown LFCM, thought to be relict $\mathrm{ZrO}_{2}$ inclusions from the crystallisation of $\mathrm{Zr}-\mathrm{U}-\mathrm{O}$ phases into high uranium-zircon. ${ }^{1,7}$ The presence of monoclinic $\mathrm{ZrO}_{2}$, in the form of baddeleyite, is rare in 

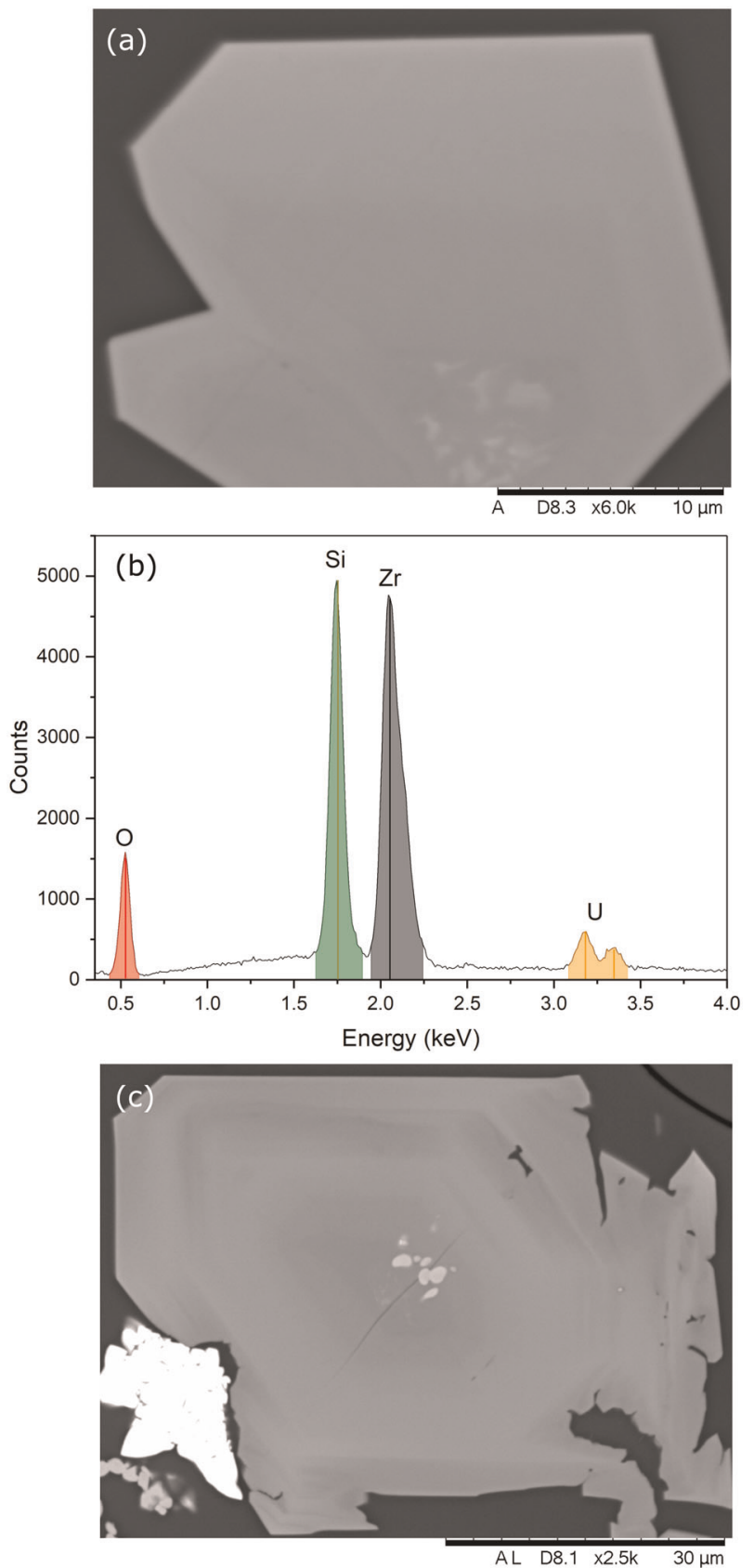

Fig. 3 Back-scattered electron micrographs of high uranium-zircon (chernobylite, $\left.\left(\mathrm{Zr}_{0.90} \mathrm{U}_{0.10}\right) \mathrm{SiO}_{4}\right)$ within simulant Brown LFCM. Showing (a) agglomerated crystals; (b) EDS data showing incorporation of uranium in the zircon phase and (c) evidence of zoning within zircon and presence of Zr-rich particles in the centre of the zircon.

the previous analysis of real LFCM; ${ }^{1,7}$ its relative abundance in this study (Fig. 1; Supplementary Fig. 1) may be due to the addition of more $\mathrm{ZrO}_{2}$ than was required to form the zircon phase. The presence of albite $\left(\mathrm{NaAlSi}_{3} \mathrm{O}_{8}\right)$, as large dendrites within the glassy matrix, is in accordance with previous observations of pyroxenelike minerals with a composition of $\left(\mathrm{Ca}_{0.08} \mathrm{Fe}_{0.02} \mathrm{Cr}_{0.02} \mathrm{Zr}_{0.02}\right)$ $\mathrm{Al}_{0.18} \mathrm{Mgg}_{1.86} \mathrm{Si}_{1.82} \mathrm{O}_{5.97}$, in particles of real LFCM. ${ }^{17}$

Thermal analysis of simulant LFCM, as determined by DTA, gave values for $\mathrm{T}_{\mathrm{g}}$ of $722 \pm 5^{\circ} \mathrm{C}$ and $732 \pm 5^{\circ} \mathrm{C}$ for the Brown and Black compositions, respectively (Table 1; Supplementary Fig. 2). This is somewhat lower than previously estimated values for LFCM. ${ }^{28}$ Two distinct crystallisation peaks were observed in both materials,
Table 1. Temperatures of key thermal events within simulant Brown and Black LFCM.

\begin{tabular}{llll}
\hline & & \\
\cline { 2 - 4 } & & Sample & \\
\cline { 2 - 4 } Thermal event $\left({ }^{\circ} \mathrm{C}\right) \pm 5^{\circ} \mathrm{C}$ & $T_{\mathrm{g}}$ & 722 & 732 \\
& $T_{\mathrm{c} 1}$ & 1006 & 1020 \\
& $T_{\mathrm{c} 2}$ & 1247 & 1243 \\
& $T_{11}$ & 1226 & 1213 \\
& $T_{12}$ & 1281 & 1359 \\
\hline
\end{tabular}

the first occurring between $1006 \pm 5^{\circ} \mathrm{C}$ and $1020 \pm 5^{\circ} \mathrm{C}$, and the second at $\sim 1245 \pm 5^{\circ} \mathrm{C}$. By application of Ti-thermometry, Poml et al. ${ }^{9}$ estimated the temperature of high-uranium-zircon crystallisation in LFCM to be $\sim 1250^{\circ} \mathrm{C}$, suggesting that the $T_{c}$ of $\sim 1245 \pm$ $5^{\circ} \mathrm{C}$ observed in this work may be related with crystallisation of zircon. This is consistent with zircon crystallisation in geological formations, where zircon is known to form at temperatures between 1300 and $1600{ }^{\circ} \mathrm{C} .{ }^{29,30}$ The lower crystallisation temperature should therefore be associated with the formation of $\mathrm{Zr}-\mathrm{U}-\mathrm{O}-$ containing phases. The samples became liquid at temperatures of $>1213 \pm 5^{\circ} \mathrm{C}$, and heating to $1280 \pm 5^{\circ} \mathrm{C}$ and $1359 \pm 5^{\circ} \mathrm{C}$ was required to obtain a crystal-free melt for simulant Brown and Black LFCM, respectively. This is somewhat lower than the estimations of the melt temperature of LFCM within the Chernobyl reactor, which range between $1400^{\circ} \mathrm{C}$ and $1550^{\circ} \mathrm{C}^{2,17}$ and may be explained by the compositional heterogeneity of LFCM. Other than the exclusion of fission products, the primary difference in composition between the real LFCM and the simulant materials analysed here is the source of $\mathrm{Zr}$. During the accident, it is thought that the first portion of liquid phases formed at $\sim 1400{ }^{\circ} \mathrm{C}$ as a result of melting of $\mathrm{U}$ and $\mathrm{Zr}$ into a $\mathrm{U}, \mathrm{Zr}$ alloy, ${ }^{2}$ after which the melt contacted construction materials forming LFCM; in this study, this stage of melting is not observed, due to the addition of $\mathrm{Zr}$ in oxide form. Furthermore, during the accident, there was a long period of melting prior to breakthrough of the lava to the under-reactor compartments, which may differ from the double-stage (but single composition) melting process used to generate the simulant LFCM. Thermogravimetric data obtained simultaneously with thermal analysis showed no appreciable mass change upon heating.

Analysis of the $U L_{\mid I I}$ edge XANES spectra acquired from bulk simulant Brown and Black LFCM samples and oxidation state standards are shown in Fig. 4. The position of the absorption edge $\left(E_{0}\right)$, and the similarity in the post-edge features with those of $\mathrm{UO}_{2}$, suggest that the average uranium oxidation state in both lava samples is close to four. This is confirmed by comparison of the extracted edge position of the lava samples to those of known oxidation state (Fig. 4; Supplementary Table 2). The mean U oxidation state was determined to be $4.1 \pm 0.2$ for the Black LFCM and $4.3 \pm 0.2$ for the Brown LFCM, which is in agreement with previous analysis of real LFCM particles by XANES. ${ }^{17}$

Lava-like fuel-containing material corrosion behaviour

The extent of corrosion of each of the LFCM samples in UHQ water at $50^{\circ} \mathrm{C}$ was found to be comparable, as shown in Fig. 5 and Supplementary Fig. 3. For both samples, the $\mathrm{pH}$ averaged at approximately $\mathrm{pH} 5$ throughout the experiment (Supplementary Fig. 3), which is $\sim 1 \mathrm{pH}$ unit lower than in the corresponding blank solutions. The normalised mass loss of $\mathrm{Na}\left(\mathrm{NL}_{\mathrm{Na}}\right)$, typically used as a tracer in the dissolution of glass materials, of the Black LFCM was greater than the Brown LFCM (Fig. 5). The normalised mass loss of $\mathrm{U}\left(\mathrm{NL}_{\mathrm{U}}\right)$ was also higher in the Black LFCM (Fig. $\left.5 \mathrm{C}\right)$, consistent with the marginally higher oxidation state of uranium in this material. 

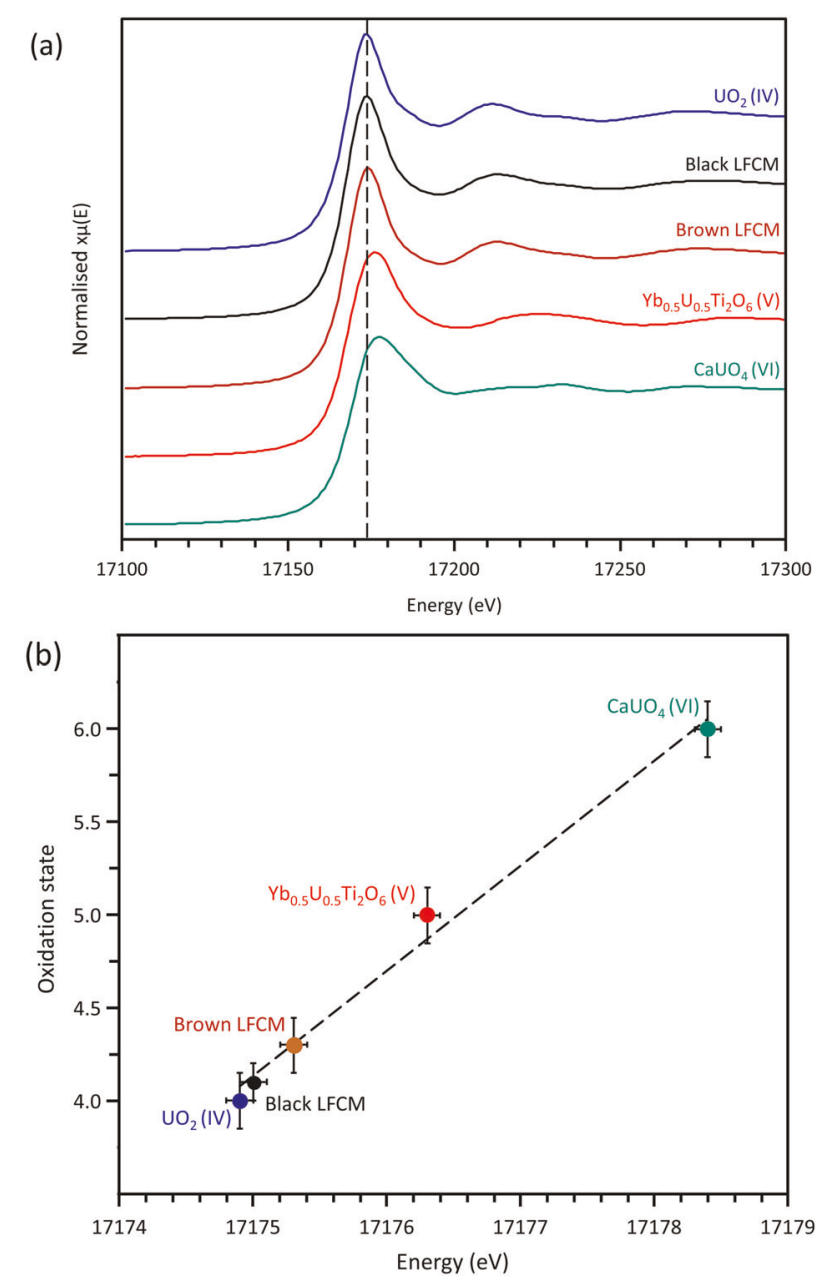

Fig. 4 Uranium $L_{\text {III }}$ edge XANES data for simulant Brown and Black LFCM, with reference to uranium standards of known oxidation state. Showing (a) showing full XANES spectra; and (b) linear regression of the extracted normalised edge position of standards and samples. Error bars represent the error on the linear regression of edge position of samples to the edge position of known standards.

There were, however, clear differences in the trend of $\mathrm{NL}_{U}$ for each of the samples after 1 day of corrosion, with the Black LFCM NLU reaching a plateau, while that of the Brown LFCM continued to increase throughout the experiment. This indicates that $U$ may be incorporated in secondary phases within the Black LFCM to a greater extent than the Brown LFCM. Given that there was a plateau in $\mathrm{NL}_{\mathrm{Si}}$ for the Black LFCM at the same time point as the plateau in $\mathrm{NL}_{U}$ (not observed for the Brown LFCM), and a Si-rich layer was observed to form on the surface of LFCM particles (Fig. 6; Supplementary Figs. 5, 6), an alternative explanation could be that further corrosion of the Black LFCM was passivated by a silica gel layer, as commonly observed for silicate glass corrosion. Zirconium was highly resistant to leaching in both materials.

The normalised mass loss of all elements from the Black LFCM (except $\mathrm{Na}$ ) reached a plateau, but those of the Brown LFCM did not. A plateau is indicative of a change in the degree of saturation of the solution with respect to these elements; such saturation phenomena are related to the formation of secondary phases on the surface of the material. Geochemical modelling of the elemental solution concentrations at 28 days predicted that smectite clay (beidellite with a general formula of $\left.\left(\mathrm{Ca}, \mathrm{Na}_{1} \mathrm{~K}_{,} \mathrm{Mg}_{0.5}\right)_{x} \mathrm{Al}_{4+\mathrm{x}} \mathrm{Si}_{8-\mathrm{x}} \mathrm{O}_{20}(\mathrm{OH})_{4} \cdot n \mathrm{H}_{2} \mathrm{O}\right)$, the phyllosilicate, kaolinite $\left(\mathrm{Al}_{2} \mathrm{Si}_{2} \mathrm{O}_{5}(\mathrm{OH})_{4}\right)$ and haematite $\left(\mathrm{Fe}_{2} \mathrm{O}_{3}\right)$ were saturated in solution for both LFCM materials, while the uranium- bearing phase, soddyite $\left[\left(\mathrm{UO}_{2}\right)_{2} \mathrm{SiO}_{4} \cdot 2 \mathrm{H}_{2} \mathrm{O}\right]$ was predicted to be in equilibrium (Supplementary Table 3 ). XRD analysis of the LFCM samples after 28 days of corrosion in UHQ water at $50^{\circ} \mathrm{C}$ (Supplementary Fig. 4) showed no change in the crystalline phase assemblage when compared with the pre-leached samples, suggesting that any secondary phases formed were non-crystalline or present only in small ( $<3 \mathrm{wt} \%)$ quantities. Analysis of samples subject to corrosion under the conditions utilised in this study (UHQ water, $50^{\circ} \mathrm{C}$ or $200^{\circ} \mathrm{C}$ ) gave evidence for the formation of Na-, Si- and Albearing alteration products for both LFCM materials (Fig. 6; Supplementary Figs. 5, 6), consistent with geochemical modelling predictions. The alteration layer was found to range from $\sim 1 \mu \mathrm{m}$ to $10 \mu \mathrm{m}$ in thickness for both LFCM compositions. No uranium-bearing alteration products were observed in either type of corrosion experiment.

\section{DISCUSSION}

The data presented in this study confirm that the synthesis of realistic low-activity (i.e., containing depleted uranium as the only radioactive isotope) simulants for Chernobyl LFCM is achievable at a small, batch scale, in the laboratory. The microstructure and mineralogy of the resulting materials were the same as found in real Brown and Black LFCMs, containing the same range of phases, including the high uranium-zircon, chernobylite, which previous studies of simulants have been unable to form. ${ }^{19-21}$ It was previously proven possible to synthesise this phase through hightemperature heat treatment of $\mathrm{U}-\mathrm{Zr}-\mathrm{Si}-\mathrm{O}$ gels, ${ }^{31}$ however, to our knowledge, this study is the first to successfully crystallise this phase from a glass melt. The LFCM simulants synthesised here additionally contained $\mathrm{Zr}-\mathrm{U}-\mathrm{O}$ phases, $\mathrm{UO}_{2}, \mathrm{ZrO}_{2}$ and $\mathrm{Fe}-, \mathrm{Ni}-, \mathrm{Cr}-$ and Mo-bearing metallic inclusions, also found in real LFCM. The identification of small inclusions of $\mathrm{ZrO}_{2}$ at the centre of chernobylite grains confirms previous hypotheses that this phase is the product of reaction between $\mathrm{Zr}-\mathrm{U}-\mathrm{O}$ and the silicate melt. ${ }^{1,7}$

One advantage of being able to create low-activity simulants is the ability to perform measurements that are otherwise difficult to conduct within a hot-cell environment. In this study, we have been able to further elucidate the thermal characteristics of LFCM, determining the glass-phase transition, liquidus temperature and the crystallisation temperatures of zircon and $\mathrm{Zr}-\mathrm{U}-\mathrm{O}$-containing phases. The latter values are consistent with those measured for natural minerals, and the former may differ slightly from real LFCM due to the use of $\mathrm{ZrO}_{2}$ as a precursor rather than zircaloy cladding. The preparation of low-activity samples is also advantageous for analysis at user facilities, for example, synchrotron beamlines. This study confirmed, by XANES, that the oxidation state of uranium in the simulant samples, which was initially added to the batch as $\mathrm{UO}_{3}$, was $\mathrm{U}(\mathrm{IV})$, as observed in real LFCM. ${ }^{17}$ In the absence of zircaloy cladding, the melting of which is thought to have partially reduced $\mathrm{UO}_{2}$ during the accident, our study required the application of a reducing atmosphere during synthesis to create the desired oxidation state.

There is a further benefit of being able to synthesise small $(25 \mathrm{~g})$ batches of realistic simulant LFCM. The use of large-scale demonstrators, where experiments are conducted to understand the interaction of molten fuel and cladding with structural building materials, such as the VULCANO facility in France, ${ }^{32}$ are expensive and hazardous to operate. Having a reliable, small-scale synthesis procedure may be helpful in screening compositions and experimental matrices so that the use of the large-scale demonstrator can be reduced to only those most important experiments; this may prove highly useful in the ongoing assessment of molten corium-concrete interaction (MCCl) products at the Fukushima Daiichi Nuclear Power Plant in Japan, ahead of fuel retrieval operations.

The corrosion behaviour of LFCM is of concern with regards to decommissioning of the Chernobyl reactor. This is due to the large amounts of radioactive dust generated from the secondary alteration 
(a)

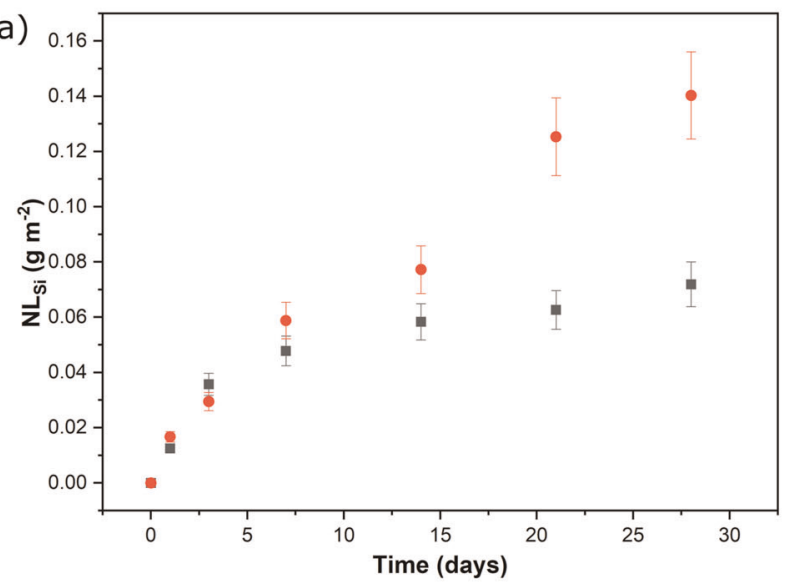

(c)
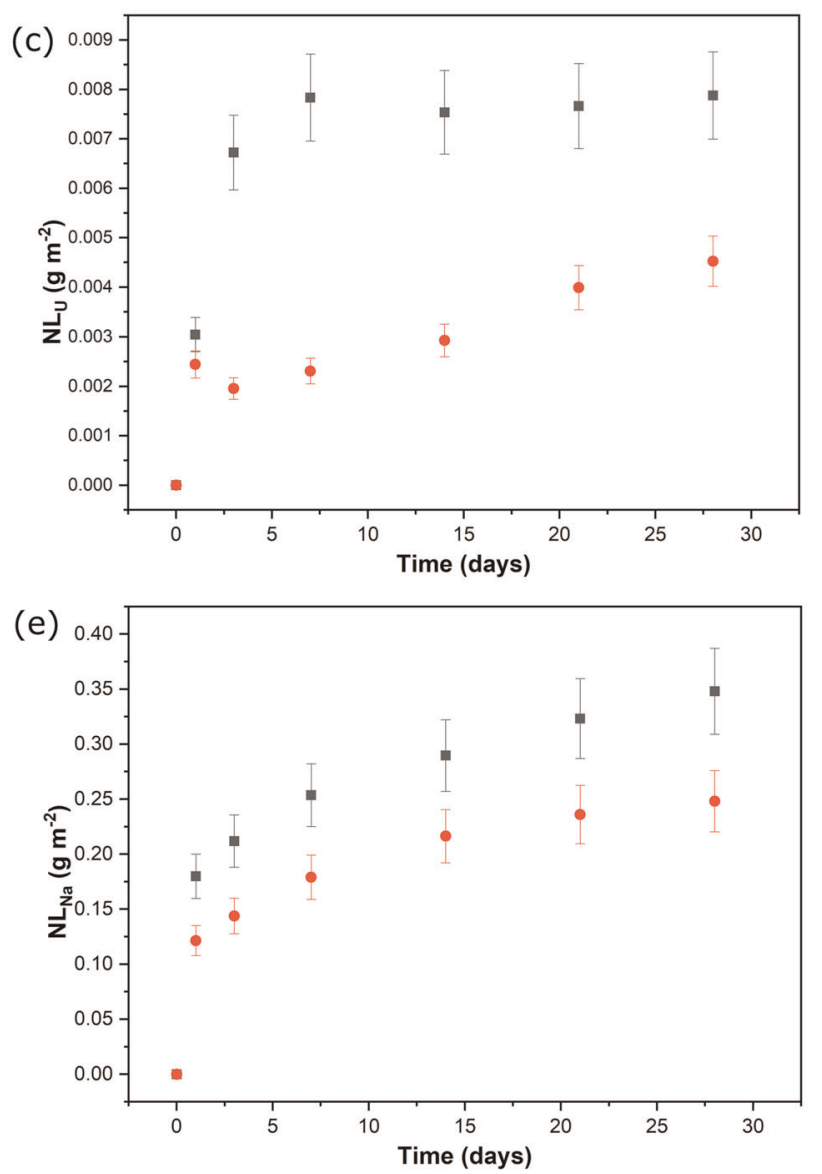

(b)
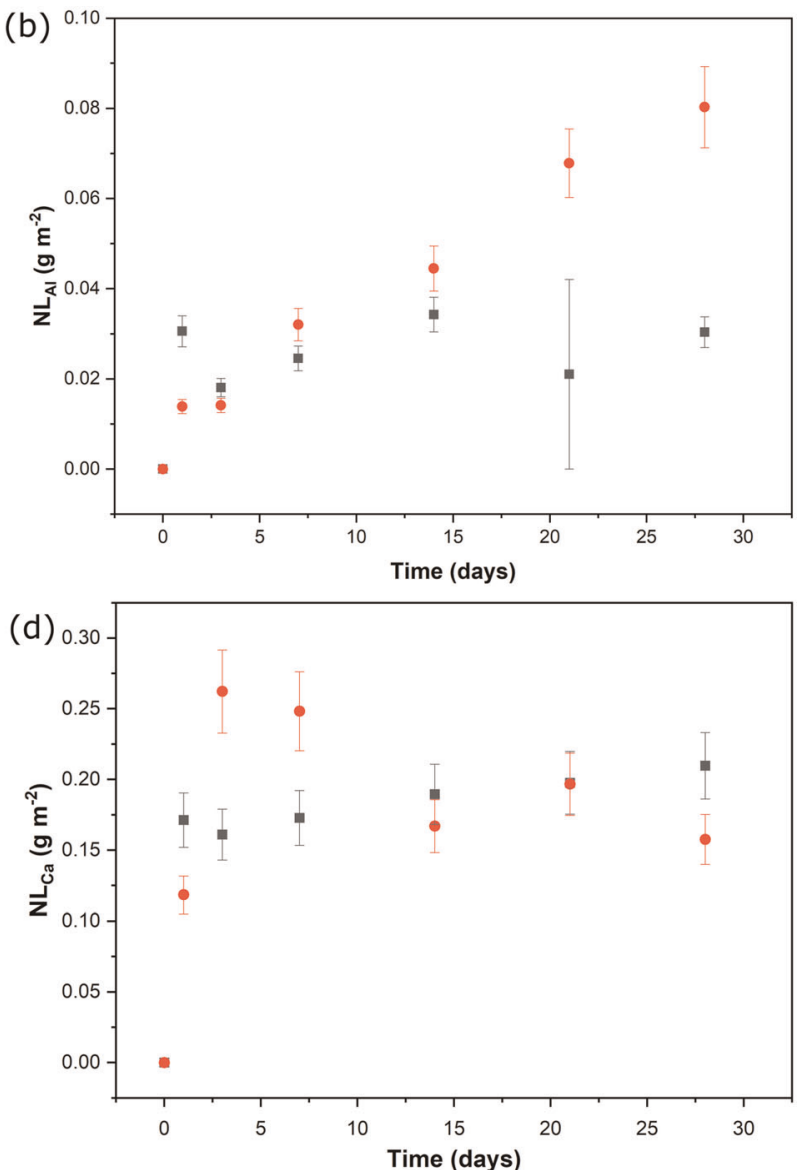

(f)

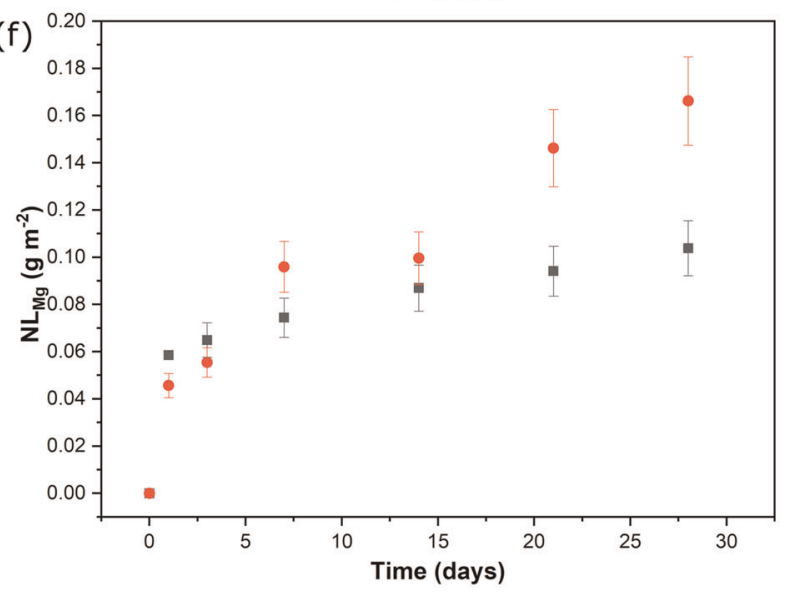

Fig. 5 Normalised mass loss $\left(\mathrm{NL}_{\mathrm{i}}\right)$ of elements from Black $(\square)$ and Brown (O) LFCM leached in UHQ water at $50^{\circ} \mathrm{C}$. For (a) $\mathrm{Si}$; (b) $\mathrm{Al}$; (c) $\mathrm{U}$; (d) $\mathrm{Ca} ;(\mathbf{e}) \mathrm{Na}$ and (f) Mg. Error bars represent the standard deviation of triplicate measurements.

products when the humidity within the sarcophagus falls; the removal of water from the LFCM surfaces can significantly intensify $\mathrm{UO}_{2}$ oxidation and dehydrate hydrous uranium-containing oxidation products, forming dust. ${ }^{27}$ Some estimates suggest that the maximum rate of dust formation in the last 33 years was on the order of $1-10 \mathrm{~kg} \mathrm{y}^{-1} \cdot{ }^{27}$ Several studies have been performed to elucidate the corrosion rate of LFCM and to ascertain the nature of the secondary alteration phases that are formed during corrosion. Many of these have been concerned specifically with the leaching rate of various fission products (e.g., ${ }^{106} \mathrm{Ru},{ }^{137} \mathrm{Cs}$, etc.) ${ }^{12,16,18}$, however, relatively few have focused on the corrosion rate of other elements in the LFCM, including uranium - the source of the radioactive dust hazard. Furthermore, the release of uranium and other radionuclides to the ground surrounding and below the reactor, may have resulted in the generation of a significant quantity of contaminated soil that will require eventual remediation, in addition to the contamination of groundwater.

The only reported corrosion rate of uranium from real LFCM pertains to monoliths of Brown material. ${ }^{12} \mathrm{~A}$ dissolution rate of $1.8 \times 10^{-3} \mathrm{~g} \mathrm{~m}^{-2} \mathrm{~d}^{-1}$ was calculated by a simple extrapolation of the normalised mass loss over a 22-day period, with samples leached in a solution of $0.4 \mathrm{~mol} \mathrm{~L}^{-1} \mathrm{NaCl}$ (initial $\mathrm{pH} 6.5$ ), at room temperature. ${ }^{12}$ Using the same method (between 3 and 28 days, to avoid the possible influence of dissolved fines on the corrosion rate) for simulant Brown LFCM, we obtain a uranium corrosion rate of $1.05 \pm 0.06 \times 10^{-4} \mathrm{~g} \mathrm{~m}^{-2} \mathrm{~d}^{-1}$ (Supplementary Fig. 7). This is 


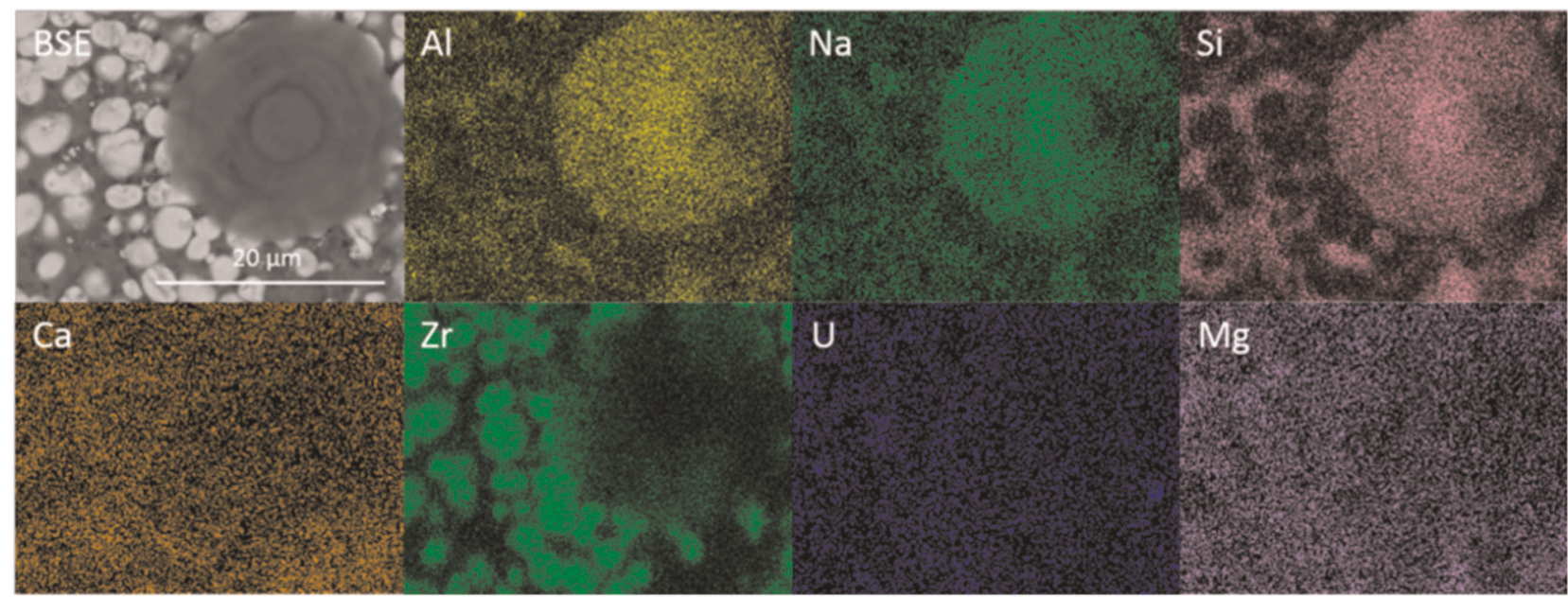

Fig. 6 SEM-EDS analysis of Black LFCM after 28 days of corrosion using the VHT method, showing the formation of a circular alteration phase.

somewhat lower than the real LFCM. Similarly, the corrosion rate of uranium for simulant Black LFCM was found to be $3.42 \pm 0.20 \times$ $10^{-5} \mathrm{~g} \mathrm{~m}^{-2} \mathrm{~d}^{-1}$. Other studies of fission product (e.g., Pu, Am, Cs and $\mathrm{Eu}$ ) leaching from real LFCM have shown no real difference in the corrosion rate between the two compositions. ${ }^{18}$ These crudely obtained uranium release rates should be treated with caution and no extrapolations to longer durations should be made, however, it is clear that the values obtained are approximately one order of magnitude greater than those for uranium leached from spent nuclear fuel under oxidative conditions, ${ }^{33}$ but are comparable with those for $\mathrm{U}_{3} \mathrm{O}_{8}$-doped borosilicate glass. ${ }^{34}$ The normalised mass loss values of $\mathrm{Na}$ and $\mathrm{Si}$ from the simulant LFCM compositions are also of the same order of magnitude as borosilicate high-level nuclear waste glass compositions such as MW $25^{35}$ or the non-radioactive simplified surrogate of French high-level waste glass, the International Simple Glass. ${ }^{36}$ The presence of a silicate alteration layer observed after corrosion (Supplementary Fig. 6) suggests that the mechanism of corrosion of LFCMs is, at least in part, similar to that of silicate glasses.

Comparing the corrosion of simulant LFCM with available data in the literature for real LFCM, the $\mathrm{pH}$ of the solutions of both were observed to decrease by $1-2 \mathrm{pH}$ units, relative to the blank, over the 28-day duration of leaching. This is somewhat unusual behaviour for alkali-aluminosilicate glasses (where the release of alkali elements to solution from the corroding glass and subsequent complexation with alkali elements raises the $\mathrm{pH}$ to alkaline values), and points to the formation of $\mathrm{pH}$-influencing secondary alteration phases, such as those that incorporate hydroxide ions (removal of which may lower $\mathrm{pH}$ ), or those that complex with carbonate ions. Within the Chernobyl sarcophagus, the carbonate concentration was found to vary between $370-2900 \mathrm{mg} \mathrm{L}^{-1}$, and uranyl carbonate mineral phases were observed to form, ${ }^{1,16,18,24,25}$ which may effectively lower the $\mathrm{pH}$. However, the present experiments contained significantly less carbonate (only that in equilibrium with $\mathrm{CO}_{2}$ in the air), and such phases were neither observed, nor predicted by geochemical modelling. It is possible that colloidal complexes containing carbonate may have formed, which were not detectable using the analytical techniques applied here, however, it seems that the removal of $\mathrm{OH}^{-}$ions into secondary phases is the most plausible explanation for the observed $\mathrm{pH}$ decrease in this study.

Further work is required to fully understand, and quantify, the corrosion behaviour of LFCM simulants; in particular, the corrosion kinetics of the simulant materials were somewhat slower than real LFCM (albeit comparing with only one study, using a simplified corrosion rate calculation) and uranium-bearing secondary precipitates, as seen on real LFCM, were apparently absent from the simulant samples. In this work, three key factors may contribute to these differences: (1) the $\mathrm{pH}$ may be too low to promote the formation of Na-uranyl carbonate phases-the $\mathrm{pH}$ of the water within the sarcophagus ${ }^{16}$ was measured as $\mathrm{pH} 8.5-10$, higher than in this study; (2) as mentioned above, the carbonate concentration within these experiments is significantly lower than within the sarcophagus and (3) most significantly, the simulant samples do not contain any alpha-emitting isotopes. Radiolysis of water by alpha particles is known to promote the formation of hydrogen peroxide (in addition to other radical species), which is known to have a significant influence on the oxidative dissolution of $\mathrm{UO}_{2}$, significantly enhancing the corrosion rate. ${ }^{37}$ Furthermore, studtite $\left(\mathrm{UO}_{4} \cdot 4 \mathrm{H}_{2} \mathrm{O}\right)$, which has been observed on real LFCM samples, is a peroxidecontaining mineral that forms by incorporating hydrogen peroxide created by alpha-radiolysis, thus requires radiation for its formation. ${ }^{38}$ Further studies are currently being performed to explore these factors, and to develop further understanding of the corrosion, and dust generation capacity of LFCMs and other fuel debris.

\section{METHODS}

\section{Synthesis}

A survey of the literature was used to ascertain the composition of Black and Brown lavas from Chernobyl; an average of all analysed samples in the literature (Supplementary Table 1) was used to produce the batched compositions shown in Table 2. When compared with the literature values, excess $\mathrm{ZrO}_{2}$ was added to the batch. Stoichiometric amounts of the reagents for each of the elements present within the LFCM samples were used $\left(\mathrm{SiO}_{2}\right.$ (Lochaline Quartz Sand 99.6\%), $\mathrm{CaCO}_{3}$ (Fisher 98\%), $\mathrm{ZrO}_{2}$ (Aldrich 99\%), $\mathrm{Na}_{2} \mathrm{CO}_{3}$ (Alfa Aesar 98\%), $\mathrm{BaCO}_{3}$ (Alfa Aesar 99\%), $\mathrm{Al}(\mathrm{OH})_{3}$ (Acros 95\%), $\mathrm{Mn}_{2} \mathrm{O}_{3}$ (Aldrich 99\%), $\mathrm{Fe} / \mathrm{Cr}_{18} / \mathrm{Ni}_{10} / \mathrm{Mo}_{3}$ (Goodfellow), $\mathrm{Mg}(\mathrm{OH})_{2}$ (Sigma-Aldrich 99.9\%) and $\mathrm{UO}_{2}(\mathrm{BDH})$ ). Batches were intimately mixed for at least $1 \mathrm{~min}$. Thermal synthesis of the loose batched powders was performed in alumina boat crucibles under a reducing atmosphere $\left(\mathrm{H}_{2}(5 \%)-\mathrm{N}_{2}(95 \%)\right.$ gas) at $1500^{\circ} \mathrm{C}$ for $4 \mathrm{~h}$ and subsequently $720^{\circ} \mathrm{C}$ for $72 \mathrm{~h}$. The ramp rate was $3^{\circ} \mathrm{C} \min ^{-1}$ at the beginning and end of the synthesis, and $1{ }^{\circ} \mathrm{C} \mathrm{min}^{-1}$ between $1500^{\circ} \mathrm{C}$ and $720^{\circ} \mathrm{C}$ steps. The second heating step was necessary to prevent shattering of the alumina crucible and to facilitate crystallite growth. The composition of the resulting materials was determined by ICP-OES (Spectro Ciros Vision) after digestion in aqua regia, as shown in Table 2. The elevated concentration of $\mathrm{Al}_{2} \mathrm{O}_{3}$ is due to corrosion of the alumina crucible during thermal treatment.

\section{Characterisation}

The crystalline-phase assemblage was determined by powder X-ray diffraction (XRD) using a Bruker D2 Phaser X-ray diffractometer in 
Table 2. Composition of simulant lava-like fuel-containing material compositions (mol\%), as batched and as determined by ICP-OES after aqua regia digest of thermally treated samples (the error on the asanalysed compositions is $\pm 2 \%$ ).

\begin{tabular}{lcccc}
\hline Component & $\begin{array}{l}\text { Brown LFCM } \\
\text { (mol\%), } \\
\text { batched }\end{array}$ & $\begin{array}{l}\text { Brown LFCM } \\
\text { (mol\%), } \\
\text { analysed }\end{array}$ & $\begin{array}{l}\text { Black LFCM } \\
\text { (mol\%), } \\
\text { batched }\end{array}$ & $\begin{array}{l}\text { Black LFCM } \\
\text { (mol\%), } \\
\text { analysed }\end{array}$ \\
\hline $\mathrm{SiO}_{2}$ & 62.2 & 59.8 & 64.2 & 65.3 \\
$\mathrm{CaO}$ & 7.3 & 7.1 & 7.7 & 6.4 \\
$\mathrm{ZrO}_{2}$ & 7.6 & 8.4 & 8.1 & 7.2 \\
$\mathrm{Na}_{2} \mathrm{O}$ & 7.9 & 6.8 & 7.3 & 4.7 \\
$\mathrm{BaO}$ & - & - & 0.1 & 0.1 \\
$\mathrm{Al}_{2} \mathrm{O}_{3}$ & 1.9 & 4.0 & 3.2 & 5.6 \\
$\mathrm{MnO}$ & - & - & 0.4 & 0.5 \\
$\mathrm{Fe}_{2} \mathrm{O}_{3}$ & 0.6 & 0.7 & - & 0.5 \\
$\mathrm{MgO}$ & 10.1 & 10.0 & 7.9 & 8.2 \\
$\mathrm{UO}_{2}$ & 2.4 & 3.2 & 1.2 & 1.5 \\
$\mathrm{Total}$ & 100.0 & 100.0 & 100.0 & 100.0 \\
\hline
\end{tabular}

reflectance mode over the range $10^{\circ} \leq 2 \theta \leq 70^{\circ}$ with Cu Ka radiation ( $30 \mathrm{kV}$, $10 \mathrm{~mA}$ ). Representative cross-sections were prepared by mounting monolith samples in resin and polishing to a $1 \mu \mathrm{m}$ finish using successive $\mathrm{SiC}$ grit papers and diamond suspension polishing solution. The morphology of the crystalline-phase assemblage was imaged using a Hitachi TM3030 Scanning Electron Microscope (SEM) with semi-quantitative analysis of mineral composition using a built-in Bruker XFlash $430 \mathrm{H}$ Energy Dispersive X-ray Spectroscopy (EDS) system. Thermal characterisation of the LFCMs was performed using Differential Thermal Analysis (DTA) of representative powdered samples using a Netzsch TG 449 F3 simultaneous thermal analyser. The glass transition $\left(T_{\mathrm{g}}\right)$, crystallisation $\left(T_{\mathrm{c}}\right)$ and liquidus $\left(T_{\mathrm{l}}\right)$ temperatures were determined, with the annealing temperature of the samples taken to within $50^{\circ} \mathrm{C}$ of the $T_{\mathrm{g}}$ observed. Helium pycnometry analysis gave densities of $3.054 \pm 0.004 \mathrm{~g} \mathrm{~cm}^{-3}$ and $2.998 \pm 0.003 \mathrm{~g} \mathrm{~cm}^{-3}$ for Brown and Black simulant LFCM, respectively.

$\mathrm{X}$-ray absorption near edge spectroscopy (XANES) analysis of the $U \mathrm{~L}_{\text {III }}$ edge was performed on Black and Brown lava samples, on beamline BL-27 at the Photon Factory synchrotron facility (Tsukuba, Japan), ${ }^{39}$ to evaluate the bulk uranium oxidation state. XANES spectra were collected between 16865 and $18265 \mathrm{eV}$ with an accumulation time of $1 \mathrm{~s} \mathrm{step}^{-1}$ and energy steps of $4 \mathrm{eV}$ (16865-17115), $1 \mathrm{eV}$ (17115-17665), $4 \mathrm{eV}$ (17665-17965) and $1 \mathrm{eV}$ (17965-18265). Multiple spectra were averaged to improve the signalto-noise ratio, and a fluorescence spectrum of a $\mathrm{Zr}$ foil was acquired simultaneously with each sample to ensure accurate energy calibration. Three crystalline standards were also measured using the same conditions. All samples were prepared by mixing finely ground powders with PEG and pressing into cylindrical disks of $13 \mathrm{~mm}$ diameter. The PEG to powder ratio was optimised to give a suitable edge step over the $U L_{\text {III }}$ absorption edge. Data reduction and analysis performed using the Athena software package. ${ }^{40}$ Linear regression of the $U L_{|| l}$ edge energy position (defined as the energy where the edge step is equal to 0.5) with respect to standards of known oxidation state $\left(\mathrm{UO}_{2}, \mathrm{Yb}_{0.5} \mathrm{U}_{0.5} \mathrm{Ti}_{2} \mathrm{O}_{6}\right.$ and $\left.\mathrm{CaUO}_{4}\right)$ confirmed the uranium oxidation state within the sample. ${ }^{41}$

\section{Corrosion analysis}

Two ASTM standard methods were used as the basis of corrosion experiments. Firstly, a modified ASTM Product Consistency Test B (PCT-B) protocol (ASTM C1205-14), ${ }^{42}$ utilising a surface area to volume ratio of $120 \mathrm{~m}^{-1}$, was performed to give insight to dissolution kinetics. LFCM materials were crushed and sieved to a powder of 75 to $150 \mu \mathrm{m}$ in size. Washed powders were placed in Teflon vessels, and $10 \mathrm{~mL}$ of UHQ water (in equilibrium with $\mathrm{CO}_{2}$ in the air) was added. Vessels were tightened and placed inside an oven at $50 \pm 1{ }^{\circ} \mathrm{C}$ for 28 days. At several time intervals, vessels were sacrificed, and aliquots of solution were taken for elemental analysis using inductively coupled plasma-mass spectroscopy (Agilent 4500) and the $\mathrm{pH}$ was measured. Experiments were performed in triplicate, with duplicate blanks and all errors reported refer to the standard deviation of triplicate measurements.
The normalised mass loss of elements within the LFCMs was determined according the following equation:

$N L_{i}=\frac{C_{i}}{f_{i} \times\left(S_{A} / V\right)}$

where $N L_{i}$ is the normalised mass loss $\left(\mathrm{g} \mathrm{m}^{-2}\right)$ of element $i, C_{i}$ is the elementary concentration $\left(\mathrm{g} \mathrm{cm}^{-3}\right)$ in the solution, $f_{i}$ is the mass fraction of element $i$, and $S_{A} N$ is the ratio $\left(\mathrm{m}^{-1}\right)$ between the surface area of the glass $\left(\mathrm{m}^{2}\right)$ and the volume of solution used $\left(\mathrm{m}^{3}\right)$. The normalised dissolution rate, $R L_{i}\left(\mathrm{~g} \mathrm{~m}^{-2} \mathrm{~d}^{-1}\right)$, is defined as the time derivative of the normalised mass loss, and was calculated using the normalised mass loss obtained from triplicate samples between 3 and 28 days, according to Eq. (2). The errors represent the uncertainty in the determination of the linear chi-square fit gradient, taking into account triplicate $N L_{i}$ values.

$R L_{i}=\frac{d N L_{i}}{d t}=\frac{1}{f_{i} \times\left(S_{A} / V\right)} \times \frac{d C_{i}}{d t}$

Analysis of the experimental data from the 28-day solutions was performed using the geochemical speciation software PHREEQC, using the Lawrence Livermore National Laboratory thermodynamic database, LLNLTDB. Data used in the LLNL-TDB are valid for temperatures ranging from 0 to $300^{\circ} \mathrm{C}$. The corroded samples were further characterised by XRD.

The second method of corrosion analysis was Vapour Hydration Testing (VHT), performed by using a modified ASTM C1663, ${ }^{43}$ to develop insight into the secondary phases formed on LFCMs during corrosion. Monolith coupons, $10 \times 5 \times 1 \mathrm{~mm}$ in size, were polished to an optical finish with successive SiC grit papers. Samples were suspended within stainless steel pressure vessels using stainless steel wire, such that all surfaces of the coupons were in contact with water vapour during the experiment. Vessels were tightly sealed and placed within a temperature controlled oven at $200{ }^{\circ} \mathrm{C}$ for 28 days. At the end of the experiment, samples were mounted in cross section in epoxy resin for SEM/EDS analysis, as described above.

\section{DATA AVAILABILITY}

The data that support the findings of this study are available from the corresponding author upon reasonable request.

Received: 1 April 2019; Accepted: 6 January 2020; Published online: 30 January 2020

\section{REFERENCES}

1. Burakov, B. E. et al. The behavior of nuclear fuel in first days of the Chernobyl accident. Mat. Res. Soc. Symp. Proc. 465, 1297-1308 (1997).

2. Ushakov, S. V., Burakov, B. E., Shabalev, S. I. \& Anderson, E. B. Interaction of $\cup_{2}$ and zircaloy during the Chernobyl accident. Mat. Res. Soc. Symp. Proc. 465, 1313-1318 (1997).

3. Pazukhin, E. M. Fuel-containing lavas of the Chernobyl NPP 4th block topography physicochemical properties and formation scenario. Radiochemistry 36, 109-154 (1994).

4. Borovoi, A. A., Lagunenko, A. S. \& Pazukhin, EM. Estimating the amount of fuel in cellar building 305/2 at Chernobyl unit 4. Atom Energy 84, 295-299 (1998).

5. Bogatov, S. A. et al. Formation and spread of Chernobyl lavas. Radiochemistry $\mathbf{5 0}$, 650-654 (2008)

6. Trotabas, M., Blanc, J.-Y., Burakov, B. E., Anderson, E. B. \& Duco J. Examination of Chernobyl Samples. Impact on the Accident Scenario Understanding. Report DMT/ 92/309, SETIC/LECR-92/36, Report IPSN/93/02, Report RI-1-63/92. Commissariat a I'energie atomique CEA Centre d'Etudes de Saclay. (1993).

7. Anderson, E. B., Burakov, B. E. \& Pazukhin, E. M. High-uranium zircon from Chernobyl "Lavas". Radiochim. Acta 60, 149-151 (1993).

8. Geisler, T., Burakov, B. E., Zirlin, V., Nikloeave, L. \& Poml, P. A Raman spectroscopic study of high-uranium zircon from the Chernobyl "Lava". Eur. J. Mineral. 17, 883-894 (2005).

9. Poml, P. et al. Micro-analytical uranium isotope and chemical investigations of zircon crystals from the Chernobyl "Lava" and their nuclear fuel inclusions. J. Nucl. Mater. 439, 21-56 (2013).

10. Borovoy, A. A. et al. New products formed by reaction of fuel with construction materials in the 4th block of the Chernobyl NPP. Radiochemistry 32, 659-667 (1990).

11. Savonenkov, V. G., Krivokhatskii, A. S., Dubasov, Yu. V. \& Pazukhin, E. M. Radioactive man-made formations from the destroyed 4th unit of Chernobyl NPP. Radiochemistry 33, 140-149 (1991). 
12. Rogozin, J. M. et al. Leaching of radionuclides from some neoformed products, excavated from the reactor area of the 4 th block of the Chernobyl nuclear power plant. Radiochemistry, 4, 160-167 (1991).

13. Kiselev, A. N., Nenaglyadov, A. Yu., Surin, A. I. \& Checherov K. P. Experimental Study of Lava-Like Fuel Containing Masses (FCM) at 4th Unit of ChNPP (Based on Results Obtained in 1986-1991) (IAE, Moscow, 1992).

14. Burakov, B. E., Strykanova, E. E. \& Anderson, E. B. Secondary uranium minerals on the surface of Chernobyl "Lava". Mat. Res. Soc. Symp. Proc. 465, 1309-1311 (1997).

15. Baev, A. S., Teterin, Y. A., Ivanov, K. E., Teterin, A. Y. \& Bogatov, S. A. X-ray photoelectron study of the samples of fuel containg masses formed as a result of the Chernobyl accident. Radiochemistry 39, 169-174 (1997).

16. Krinitsyn, A. P., Simaovskaya, I. Ya \& Strikhar, O. L. Study of interaction of water with constructional and fuel-containing materials inside "Shelter". Radiochemistry 40, 279-288 (1998).

17. Shiryaev, A. A. et al. Physico-chemical properties of Chernobyl lava and their destruction products. Prog. Nucl. Energ. 92, 104-118 (2016).

18. Zubekhina, B. Yu \& Burkov, B. E. Leaching of actinides and other radionuclides from matrices of Chernobyl "Lava" as analogues for vitrified HLW. J. Chem. Thermodyn. 114, 25-29 (2017).

19. Bondarenko, V. N. et al. Investigation of the elemental composition of surrogates of fuel-containing materials by nuclear microanalysis. Atom Energy 102, 304-309 (2007).

20. Krasnorutsky, V. S. et al. Study of the interaction of nuclear fuel with core construction materials in the case of the above design accident. BAHT, Kharkov Institute of Physics and Technology, No. (78) (2012).

21. Krasnorutsky, V. S. et al. Microstructural analysis of lava-like fuel-contained masses. Probl. Sci. Tech. 1, 60-70 (2010).

22. Barlow, S. T. et al. Synthesis of simulant 'lava-like' fuel containing materials (LFCM) from the Chernobyl reactor unit 4 meltdown. MRS Adv. 2, 609-614 (2017).

23. Krinitsyn, A. P., Strikhar, O. L. \& Shcherbin, V. N. Management of liquid radioactive waste from the shelter. Radiochemistry 45, 512-517 (2003).

24. Burakov, B. E., Strykanova, E. E. \& Anderson, E. B. Secondary uranium minerals on the surface of Chernobyl "Lava”. Mat. Res. Soc. Symp. Proc. 465, 1309-1311 (1997).

25. Teterin, Yu. A., Baev, A. S. \& Bogatov, S. A. X-ray photoelectron study of samples containing reactor fuel from lava and products growing on it which formed at chernobyl NPP due to the accident. J. Electron Spectrosc. 68, 685-694 (1994).

26. Baryakhtar, V., Gonchar, V., Zhidkov, A. \& Klutchnikov, A. in a Dust Productivity of Damaged Irradiated Fuel and Lava-like Fuel Containing Materials of "Shelter" Object (ed. Shcherbyn, V. M.) 97-10 (National Academy of Sciences of Ukraine, Interdisciplinary Scientific and Technical Centre "Shelter", 1997).

27. Badovskii, V. P., Melenevskii, A. E., Morozov, Yu. V., Ushakov, I. A. \& Shcherbin, V. N. Generation of radioactive dust by lava-like fuel containing materials at the shelter object of Chernobyl NPP. Radiochemistry 56, 311-318 (2014).

28. Gonchar, V. V. \& Zhidkov, A. V. Dynamics of high-temperature interaction of damaged nuclear fuel with construction materials of RBMK. Probl. Nucl. Power Plants Saf. Chernobyl 9, 25-33 (2002).

29. Butterman, W. C. \& Foster, W. R. Zircon stability and the $\mathrm{ZrO}_{2}-\mathrm{SiO}_{2}$ phase diagram. Am. Mineral. 52, 880-885 (1967).

30. Curtis, C. E. \& Sowman, H. G. Investigation of the thermal dissociation, reassociation and synthesis of zircon. J. Am. Ceram. Soc. 36, 190-198 (1953).

31. Burakov, B. E., Smetannikov, A. P. \& Anderson, E. B. Investigation of natural and artificial Zr-silicate gels. Mat. Res. Soc. Symp. Proc. 932, 1017-1024 (2006)

32. Piluso, P., Trillon, G. \& Journeau, C. The $\cup_{2}-\mathrm{ZrO}_{2}$ system at high temperature ( $\mathrm{T}>$ $2000 \mathrm{~K})$ : importance of the meta-stable phases under severe accident conditions. J. Nucl. Mater. 344, 259-264 (2005).

33. Oversby, V. M. Uranium Dioxide, SIMFUEL, and Spent Fuel Dissolution Rates-A Review of Published Data. SKB Technical Report TR-99-22, The Swedish Nuclear Fuel and Waste Management Co. (SKB) (1999).

34. Jantzen, C. M. \& Trivelpiece, C. L. Uranium dissolution and geochemical modelling in anoxic and oxic solutions. MRS Adv. 2, 705-710 (2017).

35. Corkhill, C. L., Cassingham, N. J., Heath, P. G. \& Hyatt, N. C. Dissolution of UK highlevel waste glass under simulated hyperalkaline conditions of co-located geological disposal facility. Int. J. Appl. Glass Sci. 4, 341-356 (2013).

36. Backhouse, D. J. et al. Corrosion of the international simple glass under acidic to hyperalkaline conditions. npj Mater. Degrad. 2, 29 (2018).

37. Liu, N., Qin, Z., Noel, J. J. \& Shoesmith, D. W. Modelling the radiolytic corrosion of a-doped $\mathrm{UO}_{2}$ and spent nuclear fuel. J. Nucl. Mater. 494, 87-94 (2017).

38. Burns, P. C. \& Hughes, K.-A. Studtite, $\left[\left(\mathrm{UO}_{2}\right)\left(\mathrm{O}_{2}\right)\left(\mathrm{H}_{2} \mathrm{O}_{2}\right)\right] \mathrm{H}_{2} \mathrm{O}_{2}$ : the first structure of a peroxide mineral. Am. Mineral. 88, 1165-1168 (2003).

39. Konishi, $H$. et al. Synchrotron radiation beamline to study radioactive materials at the Photon factory. Nucl. Instrum. Meth. A. 372, 322-332 (1996).

40. Ravel, B. \& Newville, M. ATHENA, ARTEMIS, HEPHAESTUS: data analysis for Xray absorption spectroscopy using IFEFFIT. J. Synchrotron Radiat. 12, 537-547 (2005).
41. Corkhill, C. L. et al. Multi-scale investigation of Uranium attenuation by Arsenic at an abandoned Uranium mine, South Terras. npj Mater. Degrad. 1, 19 (2017).

42. ASTM. ASTM C 1285-14: Standard Test Methods for Determining Chemical Durability of Nuclear, Hazardous, and Mixed Waste Glasses and Multiphase Glass Ceramics: The Product Consistency Test (PCT) (American Standard Testing Methods, 2014).

43. ASTM. ASTM C 1663-18: Standard Test Method for Measuring Waste Glass or Glass Ceramic Durability by Vapor Hydration Test (American Standard Testing Methods, 2018)

\section{ACKNOWLEDGEMENTS}

The authors wish to acknowledge funding for this research from EPSRC through grant agreement numbers EP/L015390/1, EP/R01924X/1, EP/M026566/1 and EP/ P013600/1 and the European Commission Horizon 2020 Research and Training Programme, Theramin, of the European Atomic Energy Community (EURATOM), under grant agreement number 755480. C.L.C. is grateful to EPSRC for the award of an Early Career Research Fellowship (EP/N017374/1), and N.C.H. is grateful for support from the University of Sheffield Global Challenges Research Fund. This research was performed in part at the MIDAS Facility, at the University of Sheffield, established with support from the Department of Energy and Climate Change. Collection of the XAS data was performed under the approval of the Photon Factory Advisory Committee (Proposal No. 2017G187); the support of Yoshihiro Okamoto (JAEA) and Noriko Usami (KEK) during the experiment is gratefully acknowledged. We thank Dr. Boris Burakov and Dr. Sergei Shiryaev for useful discussions throughout these experiments, the International Atomic Energy Agency for financial support to attend meetings on the Coordinated Research Project on the Management of Severely Damaged Spent Fuel and Corium, and also Julia Wallenius and Alexander and Elina Corkhill for assistance with Russian to English translation.

\section{AUTHOR CONTRIBUTIONS}

All authors provided substantial contributions to conception of the research performed, or the acquisition, analysis or interpretation of the data; they drafted or revised the paper; approved the final version and are accountable for the accuracy and integrity of the data and its interpretation.

\section{COMPETING INTERESTS}

The authors declare no competing interests.

\section{ADDITIONAL INFORMATION}

Supplementary information is available for this paper at https://doi.org/10.1038/ s41529-020-0108-z.

Correspondence and requests for materials should be addressed to N.C.H. or C.L.C.

Reprints and permission information is available at http://www.nature.com/ reprints

Publisher's note Springer Nature remains neutral with regard to jurisdictional claims in published maps and institutional affiliations.

Open Access This article is licensed under a Creative Commons Attribution 4.0 International License, which permits use, sharing, adaptation, distribution and reproduction in any medium or format, as long as you give appropriate credit to the original author(s) and the source, provide a link to the Creative Commons license, and indicate if changes were made. The images or other third party material in this article are included in the article's Creative Commons license, unless indicated otherwise in a credit line to the material. If material is not included in the article's Creative Commons license and your intended use is not permitted by statutory regulation or exceeds the permitted use, you will need to obtain permission directly from the copyright holder. To view a copy of this license, visit http://creativecommons. org/licenses/by/4.0/.

(c) The Author(s) 2020 